\title{
TEACHERS DIALOGUING ABOUT STATISTICAL LITERACY WITH SUPPORT OF MESSENGER APP FOR SMARTPHONES
}

\author{
Sérgia Oliveira ${ }^{1}$, Liliane Carvalho $^{1}$, Carlos Monteiro ${ }^{1}$ and Carolina Carvalho ${ }^{2}$ \\ ${ }^{I}$ The Federal University of Pernambuco - UFPE, Brazil \\ ${ }^{2}$ The University of Lisbon, Portugal
}

\begin{abstract}
Despite the possibilities of interactions and sharing information, only few studies investigated the use of messenger apps as a pedagogical tool. This paper reflects on possible uses of messenger app as a way to share and expand knowledge about the teaching and learning of statistics. The discussion is based on theoretical perspectives on statistics education, critical mathematics education and M-learning. A pilot study was conducted with early years elementary school Brazilian teachers. In this paper we discuss results from participants' responses to an online questionnaire. The results indicated that participants frequently use WhatsApp application and email on daily basis. Regarding the teachers' previous teaching of statistics, their responses suggested that they know about statistical graphs and they already approached pedagogical activities on statistical contents. Further stages of this study will explore in-service teacher education situations in which the use of Whatsapp might assist discussions and elaborations of pedagogical activities in school and extra-school contexts.
\end{abstract}

\section{KEYWORDS}

Statistical Education, Dialogue, M-learning, Messenger App

\section{INTRODUCTION}

People experience the impacts of mobile technologies in their lives, such as frequent access to a large volume of data, including statistical data (Campos, Wodewotzki and Jacobini, 2011). Cazorla and Santana (2010) emphasize the importance of providing citizens with the possibility of being statistically literate, in order critically interpret statistical data presented by different social medias. Gal (2002) considers that people become statistically literate when developing skills that involve elements of knowledge (e.g., mathematical knowledge, statistical knowledge) and dispositional elements (e.g., critical attitudes). Statistical literacy can enable people to understand and discuss statistical data. The schooling has a crucial contribution to develop statistical literacy, and school teacher have important role to mediate students' learning about statistics, proposing reflective activities that involve dialogical investigative perspectives.

In studies on continuing teacher education to promote possibilities for statistical literacy, the authors Carvalho (2015) and Oliveira, Carvalho, Monteiro e François (2018) argue that dialogic processes permeate all stages of the investigative cycle, from the elaboration of research problem to the communication of results. The teachers participating in these studies argue that face-to-face meetings would have been insufficient to deepen debates and ideas about approached concepts. These results studies motivated us to reflect on technology utilization that could broaden dialogue between teachers beyond presential meetings.

Alro and Skovsmose (2006) define that the action of dialogue is constituted of conversation exercises about research, in which participants want to discover something to construct knowledge and develop new experiences. When we talk, we abandon the convenience of certainties to take risks, expressing opinions and expressing a worldview that can be confronted and challenged. Dialogic interactions promote relationships of equality based on interpersonal communications. The dialogical relationships from interactions presuppose the freedom of each person to exercise their learning processes (Freire, 1972). In addition, such relationships must be situated in collaborative research processes in which individuals reflect on what they know and what they 
do not yet know. In this sense, dialogic interactions should promote equality, considering the roles of teacher and student, including knowing how to deal with diversity and differences in the classroom.

Considering that vast majority of Brazilians frequently use messenger app for smartphones, such as WhatsApp, we would like to explore possibilities in teacher education. In this paper, we present results from a pilot study to diagnose the uses of WhatsApp by teachers in school and non-school situations. Our questions related to the possibility of dialogic communication between teachers, in order to develop statistical literacy.

\section{WHATSAPP AS A TOOL FOR M-LEARNING}

Mobile learning (m-learning) consists of a research field focused on theoretical and methodological discussions on the inclusion of mobile technologies in education. In this paper we base our discussion on the perspective that consider m-learning as a tool that can contribute to a more flexible education, capable of creating new learning contexts through interactive processes between people, technologies and environments (Traxler, 2009). Despite the importance of m-learning in learning, there is a contrast in school with realities which students find outside educational environments (Schofield, 2011). For example, although smartphone are devices which comprise a range of materials that students and teachers take to school and use them, as well as they could contribute to learning processes, they are not usually encouraged to use in teaching situations.

Sharples, Arnedillo-Sanchez, Milrad and Vavoula (2009) states that m-learning is a characteristic of current era that enables mobility of learning. For these authors, it is only possible to conceptualize m-learning by adding to the existence of two components: mobile and learning. The term mobile also refers to movement of people and mobility to access to information, contents and learning contexts. Its use does not impose spatial or temporal constraints, allowing students to learn math with a more focused approach to their needs.

According to Silva (2013), m-learning plays an important role in the development of educational methods, as it deals with a new form of relationship between individuals, learners and learning content. In addition, it allows actions in the educational act to be negotiated and streamlined beyond pre-established contexts. According to Oliveira (2014), one of these possibilities is the use of the WhatsApp application as a m-learning platform, which can be an effective alternative to mediate teaching and learning processes. Using WhatsApp environment allows you to exchange information, share ideas, experiences, resolve questions, gain access to a wide range of resources and materials such as text, images, audios, videos, games, links, news, e-book's and various content. These elements can strengthen interactions between students and teachers beyond the classroom, thus creating possibilities for emerging meaningful dialogues for the educational process.

The use of WhatsApp in the educational context, we can cite as an example the study by Souza and Pereira (2019), which investigated the use of WhatsApp as a facilitating tool in a process of continuing education for teachers in Brazilian rural schools. The choice of WhatsApp was justified for two reasons: first because it was widely used by the research subjects as an agile means of communication and, second, due to the wide range of this software that has an easy, intuitive and free interface. In addition, considering some difficulties, such as long hours, as well as distance and travel time, these authors realized the possibility of including the WhatsApp application as a virtual learning environment, which can be used to minimize adversities and expand the discourses. Through a semi-face-to-face training model, WhatsApp was the tool by which all non-face-to-face interactions between articulating teachers and teachers in training took place. These authors concluded the study by stating that WhatsApp was configured as an important tool to expand dialogues beyond the school environment, promoting instant and reciprocal interaction between subjects, bringing together all participants in this virtual environment. In this space, the articulating teachers were able to propose reflections and activities to the teachers in training, who had the opportunity to interact with each other throughout the activities. Thus, the subjects were able to share knowledge and experiences in order to enhance the training process.

\section{METHOD}

This paper discusses aspects of a research study in the context of Brazilian mathematics and statistics education fields, in which studies about the use of mobile technologies is still early stages. The ongoing is exploring the use of WhatsApp as a tool to be utilized in teacher education situation about statistics topics. We expect that 
the development of activities which involve face-to-face and online interactions can contribute to experiences with stages of statistical investigative cycle.

In this article we present empirical data that was collected through a questionnaire available online, which was shared through the WhatsApp application. The aims of this data collection were to identify if and how the WhatsApp app is used by teachers in in-school and out-of-school situations and verify teachers' prior knowledge about teaching statistics from the perspective of statistical literacy.

We used the resources of Google Form and produced a total of 18 items: 4 items were about teachers' professional profile; 6 items asked questions to identify what the teachers knew about statistics topics; and 9 items were related to their use of WhatsApp. Most of items demanded written answers and only 03 items provide alternative responses.

The data collection was developed with teachers from a public school located in the Metropolitan Region of Recife, Brazil. The school pedagogical coordinator explained the study for the teachers and asked them for volunteers. Seven teachers positively responded the invitation and allowed to give their WhatsApp contact to the researcher. The questionnaire was sent on those volunteers by WhatsApp. Six teachers responded the questionnaire. All participants have university degree in Pedagogy, and they teach in early years of elementary education in Brazilian public schools.

Further stages of the research project will have data collection from presential teacher group meetings about statistics education, dialogues from participation in a WhatsApp group. The main statistical topic is going to be investigative cycle from the perspective of statistical literacy. The data analysis is going to focus on characteristics of dialogues with and without WhatsApp use, seeking to verify articulations of cognitive and dispositional dimensions of statistical literacy.

\section{RESULTS}

The responses pointed out that WhatsApp was the application that the participants use most on their mobile device. Other apps which they often used are related to social networks such as Facebook, Instagram and Twitter. The frequencies of use are lower for apps associated with videos and music, such as YouTube, Deezer and Spotify. Considering the data presented, it is observed that WhatsApp is the application most used by teachers, indicating, therefore, a great potential for use, including for educational purposes. The perspective of academic use of this tool comes from the verification of the previous technical knowledge of this application by the teachers. Therefore, the WhatsApp tools are used in everyday situations by teachers. Therefore, it presents a great opportunity that has not yet been properly explored.

Another item asked about how often they use the WhatsApp application in their daily lives, and all participants responded that they use it for different situations in your daily routines. We conjecture that this resource can be valuable in boosting pedagogical interactions between teachers, between the teacher and the educational institution or even in communication with the students' parents. We also asked them if they had already planned any pedagogical activity or carried out any work in the classroom that involved students in discussions about statistics. All teachers reported that throughout their career they have already developed activities with the content of statistics. We also observed a similarity in the teachers' responses, since everyone reported that they managed to approach this curricular content based on statistical research. All teachers also informed that they always choose to highlight and compare students' responses using tables and graphs.

\section{CONCLUSIONS}

From the analysis of questionnaire, we identified that teachers in the early years of elementary school in Brazilian schools usually carry out pedagogical actions that involve the contents of statistics. We believe that, combining the theoretical knowledge that these teachers already have with their technical skills and experiences with communication through the WhatsApp application, it promotes innovation and dynamism in the pedagogical actions in the classroom. Thus, we believe that projects are needed that approach the current reality of students, contributing to the improvement of the teaching and learning dynamics of Statistics and providing the subjects with greater capacity to understand and criticize the context that surrounds them. 
Teachers can take advantage of this resource to exchange ideas and debate about the elaboration of activities, or in the discussion with colleagues about what was worked well or did not go well in their classroom. As for the potential of using this tool to promote the expansion of dialogue between teachers, it could be used in several situations, such as debates and sharing tasks. In addition to the exchange of experiences, it can also favor the emergence of new possibilities for pedagogical innovation that contribute to teaching.

This paper aimed to reflect on the possible uses of WhatsApp in continuing education processes of teachers on teaching and learning statistics. Through the discussions raised, it was possible begin reflections about how this application has been used as a m-learning resource in the context of the formative processes of elementary school teachers. Overall, research, though sparse, provides evidence that WhatsApp can contribute to greater student and teacher engagement in math classes, as well as other areas of knowledge, and that dialogue permeates all interaction actions that m-learning promotes. In addition, the use of technologies can contribute to the development of statistical thinking

\section{ACKNOWLEDGEMENT}

This study is financed by the Coordenação de Aperfeiçoamento de Pessoal de Nível Superior - Brasil (CAPES).

\section{REFERENCES}

Alro, H. and Skovsmose, O., 2006. O diálogo e aprendizagem em educação matemática. Autêntica, São Paulo.

Campos, R. C. et al., 2011. Educação Estatística: teoria e prática em ambientes de modelagem matemática. Belo Horizonte: Autêntica.

Carvalho, L. M. T. L., 2015. Letramento Estatístico: abordagem no âmbito de um curso de formação de professores de EJA. In: Porto, Z. G.; Carvalho, R. T. Viver o escrever e escrever o viver: lições da prática. NUPEP, Recife, pp 63-76.

Cazorla, I. and Santana, E., 2010. Do Tratamento da Informação ao Letramento Estatístico. Itabuna: Via Litterarum.

Freire, P., 1972. Pedagogy of the oppressed. Nova Iorque: Herder and Herder.

Gal, I., 2002. Adults Statistical Literacy: meanings, components, responsibilities. International Statistical Review, The Hague, Vol. 70, n. 1, pp. 1-25.

Oliveira, E. D. S., 2014. Proposta de um modelo de cursos baseado em Mobile Learning: Um experimento com professores e tutores no WhatsApp. - ESUD - XI Congresso Brasileiro de Ensino Superior a Distância. Anais...

Oliveira, S., Carvalho, L., Monteiro, C., François, K., 2018. Collaboration with Ororubá Xukuru teachers: reflecting about statistics education at indigenous schools. EM TEIA - Revista de Educação Matemática e Tecnológica Iberoamericana, Vol. 9, pp. 1-15.

Schofield, C. P., 2011. Going Mobile in Executive Education: how mobile technologies are changing the executive learning landscape United Kingdom, Ashridge Business School.

Sharples, M., Arnedillo-Sanchez, I., Milrad, M., and Vavoula, G., 2009. Mobile Learning: small devices, big issues. In: Balacheff, S et al. Technology-Enhanced Learning: principles and products, The Netherlands: Springer.

Silva, L. F. Mobile Learning: Aprendizagem com mobilidade. Colloquium Exactarum, v. 06, p. 01, 2013.

SOUZA, V. V., PEREIRA, E. C., 2019. O Software de Mensagens Instantâneas Whatsapp Enquanto Ferramenta Facilitadora na Formação de Professores das Escolas do Campo do Rio Grande/RS. Revista Latino-americana de Estudos em Cultura e Sociedade, Vol. 1, n. 8, pp.1-20.

Traxler, J., 2009. Current State of Mobile Learning. In: Mobile learning: transforming the delivery of education and training, M. Ally, Canada, AU Press, p. 9-24. 